\title{
Empowerment through religion: religion's survival strategies in democratic politics
}

\begin{abstract}
In contemporary Western world religion has long lost its status of a default legitimating formula and has been relegated, in liberal political philosophy, to the private sphere. Institutionally, religious organizations have been largely separated from government institutions. Despite these adverse circumstances, religion - both as a system of ideas, values and norms and in its institutional expression - has adopted effective survival strategies guarding it from social and political marginalization. Religion has been accorded special status among other ideologies. In science, it results in a sort of methodological agnosticism, which treats religious and scientific statements as belonging to two incommensurable spheres. In politics, religious organizations are often granted special legal status among other political actors and religious freedom has been constitutionalized as a special case of general freedom of expression. As judicature and political practice show, religious arguments can often trump non-religious claims when fundamental value conflicts arise. In their political activity, religious organizations have used strategies characteristic for other political actors (lobbying, mass mobilization etc.), thereby gaining democratic legitimacy, as well as unique, religion-specific strategies. Armed with these and other empowering tools, religion can continue to influence democratic political systems in significant ways.
\end{abstract}

Key words: religion and politics in Poland; religion and politics in USA; political science of religion; political movements; religious political actors in liberal democracy

$\mathbf{R}^{\mathrm{s}}$ eligion has demonstrated tremendous survival potential despite all the adverse circumstances that would seem to render it dysfunctional and generally obsolete in the modern era. The prophecy of its decline, at least in the Western world - the secularization thesis - has been challenged on many counts ${ }^{1}$ (Casanova, 2012, pp. 11-20), and the debate now centers around the question of just why religion is there to stay, not why it has to go. The explanations range from the standard functionalist account of the unifying role that religion, with its shared beliefs and commonly practised rituals, plays for social groups, to recent evolutionary approaches, where certain components of religion - such as the image of supernatural beings, the afterlife, group rituals - are seen as firmly grounded in some cognitive features of humans shaped by natural selection and other evolutionary processes (Atran, 2002; Wilson, Green, 2007). If one is to accept these sociological or evolutionary explanations, or some combination thereof, religion apparently has enough cohesive and adaptive potential to remain a significant presence in human societies.

The focus of the paper, however, is on the survival of religion in democratic politics, not its general position in society. Religious organizations will thus be seen from the

${ }^{1}$ Particularly as a prediction of the decline of religion, although it may still have value as an analysis of the processes of modernization. 
perspective of political science as political actors: social subjects attempting to influence power relations within a political system in order to achieve their goals. These religious political actors embrace a set of beliefs and norms - religious doctrine and law - which motivate and guide their behavior and which, from our vantage point, constitute a political ideology on which these subjects act. Strategies of political action used by religious organizations vary; some of them are peculiar to religion, but most are shared with the majority of secular political actors.

Such equating churches and other religious organizations with political actors is obviously an intended simplification. It is not to imply that politics is essential to these organizations and their members; on the contrary, it is often peripheral to their supernaturally grounded mission. Neither it is correct to forget the significant differences between religious and secular political actors. For instance, while the former treat their norms and beliefs as God-given and thus objectively valid and unshakable, viewing politics as a sphere of implementing these principles, the latter may evaluate their ideas - to which no comparable ultimate importance is attached - in light of their political effectiveness on the way to what often becomes the ultimate goal, power itself. But despite these and other differences, a political scientist is justified in a desire to impose a unified theoretical framework, i.e. treating all social subjects as political actors to the extent they intentionally alter power relations and influence decision-making processes within a political system (see: Kowalczyk, 2014, pp. 127-131 for various interpretations of the church's presence in the public sphere).

It is assumed here that religion plays a significant role in the political systems of contemporary Western democracies, although this is certainly not equally true for all Western countries. I will be using empirical examples mainly from Poland and the United States, studying them, as already noted, from the theoretical perspective of the political science of religion. The analysis begins with ideological, normative (philosophical) and institutional factors that inhibit faith-based activity in the public sphere, thus making it a priori unlikely for religion to survive as a significant political actor. I then argue that religion has been able to overcome these obstacles thanks to the strategy of 'special status' - seeking a privileged position among other systems of ideas and values - and through political activity in a friendly, pluralistic democratic public sphere, where they gain democratic legitimacy by using tactics similar to other political actors (a 'mimicry strategy'), in addition to strategies unique to religious organizations. ${ }^{2}$

\section{Against the odds}

To pose the problem of religion's survival as a political force in contemporary Western democracies is to assume that it is somehow against the odds. But why precisely? What are these inhibiting factors that would make it a priori unlikely for religion to play a major role in democratic political systems, despite the generally accepted view of it as

${ }^{2}$ It may be worth noting that each time I talk about religion "using a strategy", "trying to achieve something" etc., I do not attribute to it the same type of agency. Some phenomena beneficial for religion are social processes beyond the scope of intentional activity of any social subject, while others are brought about by the actions of religious organizations. 
a more or less permanent feature of the cultural landscape of human societies? There are at least three mutually connected groups of such factors.

A. Ideological. Ever since early modernity, religion has been gradually losing its status as the default legitimation formula it enjoyed in ancient and medieval times. Religion served to legitimize political power - to justify the rulers' demand of submission of the ruled - on various levels. It explained the existence of political power itself as an extension of the original act of the emergence of the cosmos out of chaos; it justified the unequal distribution of important social assets, and the resulting stratification inherent in all power relations; it defined the status of rulers as divine, priestly or, in any event, god-sanctioned; and it provided a symbolic and ceremonial framework to succession procedures - acts constitutive of political power (Poggi, 2001, pp. 77-79; Giuriato, 2009). In the European context, Christianity successfully performed these and analogous functions from Constantine to the Middle Ages, ${ }^{3}$ until it was replaced by other legitimating ideas. It was a long and gradual process, in which the growing "disenchantment of the world" (to borrow Weber's term), a sociological fact, coincided with developments in Western political thought. As a result, the theocratic ${ }^{4}$ legitimation formula gave way to other justifications, such as traditional, meritocratic and, most relevantly to contemporary democracies, the contractual legitimation formula, according to which political power originates from a social contract and is based on the ideas of the will of the people and popular sovereignty. So, however it may be in other civilization circles (Muslim or tribal societies, for instance), political leaders of Western democracies are no longer obeyed because of any sort of divine mandate.

B. Normative. Along with this process of stripping religion of its legitimating status, liberalism has been established as an axiological foundation of Western political systems - they have become liberal democracies. Liberalism, true to its individualistic spirit, is hostile to religion as a public ideology that puts forward claims to absolute truth and requires of the believers loyalty that supersedes their civic duties and attachments (Carter, 1993, p. 55). In its essential distinction between public and private spheres, modern liberalism relegates religion to the latter, where it can enjoy the protection analogous to any other intellectual or spiritual pursuits of a person, but cannot behave as a collective political actor. The "naked public square" (Neuhaus, 1986), in the meantime, is the domain of a neutral state and citizens acting from rational, non-absolutist motives.

A similar view of the public sphere is postulated by many proponents of deliberative democracy, an alternative model of liberal democracy which advocates increased participation of citizens in arriving at political decisions. According to this conception, the public forum should only be accessible to arguments formulated in the pursuit of the common good and based on rational premises and thus comprehensible, if not necessarily convincing, to all sides of the debate (Cohen, 2007, p. 220).

3 "Successfully" does not necessarily mean without conflicts between confessions and sects within Christianity or between the Church and secular rulers (over investiture, for instance). Nonetheless, nobody seriously challenged the basic belief in the divine origin of power, even if the particulars of the relations between God and the ruler, whether it was mediated by the Church etc., were hotly disputed.

4 "Theocratic" refers here to the source of legitimacy of power, not the religious or secular status of leaders. Theocracy is thus, in my terminology, a political system which derives its legitimacy from the supernatural sphere, not the rule of religious functionaries (which I call hierocracy). See: Potz, 2013, p. 414. 
Religiously motivated views do not qualify, because, ultimately, they are rooted in the belief in god as the source of moral principles. As such, they are not rational - not subject to modification as a result of deliberation and unlikely to yield to a secular conception of the common good prevalent in the community (Potz, 2010, p. 113).

C. Institutional. The objective process of 'disenchantment' and the normative liberal injunctions against the presence of religion in the public sphere were accompanied by institutional developments which also worked against religion's political role. The intensified processes of functional differentiation in the $19^{\text {th }}$ and $20^{\text {th }}$ centuries saw churches withdrawing from social spheres of their traditional activity (health service, education, social care etc.), which became colonized by specialized agencies of the state. Politically, any institutional links between religious organizations and government organs were severed and the state became fully secular. Even in countries which retained a formally established state religion - such as English Anglicanism - the actual influence of the church on the state is insignificant. As a consequence, the separation of church and state came to be seen as a cornerstone of liberal democracy, even if, in practice, it appears in many different variations across the Western world. In the USA, "[n]otwithstanding that some Americans had doubts concerning separation, growing numbers celebrated it as a constitutional right. [...] separation became established in popular opinion and eventually even in judicial opinions as a fundamental First Amendment freedom" (Hamburger, 2002, p. 391) - even though it can be plausibly argued that the constitution did not require separation, and in any case not in the strict version that emerged from Supreme Court decisions since the 1940s. The principle of the separation of church and state, even if it does not preclude the political activity of religious organizations, deprives them of the privileged status of official religions institutionally linked with the state, thereby demoting them to the rank of one among many political actors populating the public sphere.

So how does religion manage to survive as a significant political force despite these adverse social, philosophical and institutional developments that would seem to render it obsolete as a political ideology and unwelcome in the public sphere? Two such broad strategies of survival can be identified which, combined, contribute to the sustained presence of religion in the public field of the contemporary Western world. On the one hand, religion claims special status among other systems of beliefs, ideas and values on philosophical, legal and institutional levels. On the other, religious organizations behave as political actors within the political system. In this capacity, they both emulate the behavior of other, secular actors (the 'mimicry' strategy), thereby gaining fresh legitimacy in democratic politics, and use unique, religion-specific methods, unavailable to their secular counterparts. Let us look at these strategies in turn.

\section{Special status}

On the most fundamental level, religion - and especially Judeo-Christian religions - claims special status as a system of beliefs about the world and the human being, their nature, origins and future, which must not be examined by the methods of science. Religious statements should not undergo scientific scrutiny, it is argued, not because sci- 
ence is in itself essentially wrong (a fundamentalist view that most mainstream Christian denominations would readily reject), but because science and religion deal with two different and ultimately incommensurable spheres - they belong to "non-overlapping magisteria" (Dawkins, 2008, pp. 77-83)..$^{5}$ Religion's statements about God, the afterlife and even the origin of the universe are beyond the scope of scientific research, cannot be falsified and therefore should not be questioned, even when these statements do in fact overlap with reality (Christianity, after all, is not a sort of a deus otiosus deism, but a religion with God actively involved in the everyday running of the world. Scientific and theological claims are thus alternative, and often mutually exclusive explanations of the same phenomena). The measure of success in imposing such a view is that it is articulated not only by theologians, but by scientists themselves, including natural scientists. It is quite common for cosmologists, for example, to suspend their scientific judgment when it comes to the origins of the universe beyond the Big Bang or the explanation of its internal order, leaving a space for religion to answer these questions (Delumenau, 1993). It became politically incorrect, it seems, to publicly question the statements of religion from the scientific perspective. The practical political consequence of such an attitude is that religion receives preferential treatment vis-à-vis other belief systems. Religious instruction in schools, for instance, is often directly or indirectly financed with public funds. Why not instruction in astrology, alchemy or geomancy? Because they are considered false, and such an assessment is made from the point of view of science. No similar scientific assessment of religion is performed as a matter of public policy.

This general atmosphere of uniqueness surrounding religion in the public sphere - a sort of a secular halo - facilitates the creation of a legal and institutional setting in which it is easier for religious organizations to survive as political actors. This setting is usually referred to as "church-state" relations: a set of legal regulations, but also less formal arrangements contingent on the political culture of a society, that define the position of religion in general and religious groups in particular, in the public sphere. Some of these regulations are common to various third sector, i.e. non-governmental, non-business public actors (NGOs or other types of associations), such as registration procedures or some tax exemptions. Others, however, may single out religion for special treatment against secular ideologies, as well as favor some religions over others. Examples include the existence of an official state church (e.g. Great Britain, Iceland, Denmark, Norway, Greece, Malta, Liechtenstein ${ }^{6}$ ); religious invocations in the preambles of constitutions (e.g. Poland, Ireland, Greece ${ }^{7}$ ); a unique legal basis for the status of a church (concordat in Catholic countries); unequal levels of legal recognition of various religious organizations (e.g. Poland, Germany, Belgium); privileges for religious functionaries in comparison with the personnel of secular organizations (tax exemptions for priests, their release

${ }^{5}$ The term "non-overlapping magisteria" (NOMA) originally comes from Stephen J. Gould's Rocks of Ages.

${ }^{6}$ See: Constitution of the Republic of Iceland, art. 62; The Constitutional Act of Denmark, art. 4; Constitution of the Kingdom of Norway, art. 16; Constitution of Greece, art. 3; Constitution of Malta, art. 2; Constitution of the Principality of Liechtenstein, art. 37.

${ }^{7}$ Constitution of the Republic of Poland, Constitution of Ireland, Constitution of Greece. See: Szymanek, 2011, for a general discussion of the constitutional expression of the idea of a confessional state. 
from military service where it was compulsory); government-supported religious instruction in public schools, either in the form of (compulsory or optional) lessons paid by the state (e.g. Scandinavian countries, Malta, Poland, Belgium, Germany, Italy, Alsace in France - Llorent-Bedmar, Cobano-Delgado, 2014; Furniere, 2015; Stewart, 2016) or some form of released-time program (USA); financial support for religious organizations from public coffers, in the form of grants to religious schools of various levels, tax exemptions, maintenance of church property, etc.; religious settings for public ceremonies. Particular arrangements and the extent of such preferential treatment vary, of course, across the Western world (with France being on the opposite pole to Greece, Poland or Ireland), but the very notion of "church-state" relations suggests a special position of religious organizations among other public actors. One does not, after all, talk about "NGOs-state relations", "interest groups-state relations" or "political parties-state relations". This perspective is, to a certain extent, supported by political scientists' and particularly legal scholars' use of "church-state" as a paradigm for the study of the relationship between religion and politics, in preference to the more explanatorily powerful and less normatively burdened framework of the political science of religion.

This preferential attitude to religion is sometimes so deeply embedded in the normative foundations of Western political systems that it often goes almost unnoticed. It rarely strikes anyone as controversial that religious liberty should be among the "first freedoms," one of the most fundamental human rights. Yet it does attest to religion's uniqueness. In fact, even though religious freedom is merely a special case of the general freedom of expression (the difference lying only in the content of the expression), its scope has been routinely extended beyond it. In the United States, the Supreme Court interpreted the "free exercise" clause of the First Amendment to the Constitution to grant religious believers exemptions from generally applicable laws if these laws burdened their exercise of religion. In a landmark case, a Seventh-Day Adventist was allowed to retain her unemployment benefit despite refusing to work on Saturday (which the law required), because executing the regulation would force her into the dilemma of violating the principles of her religion (Saturday is the holy day for Sabbatarian Christians, including Seventh-Day Adventists) or forfeiting her benefit (Sherbert, 1963). ${ }^{8}$ Similar exemptions are not granted to sincere followers of secular ideologies or non-mainstream or quasi-religions (for instance, Scandinavian mythology aficionados who might demand Thursday - the day of Thor - as a day off work). It has always been much easier to obtain exemption from military service, where and when it was compulsory, by invoking religious rather than secular justification for one's unwillingness to serve. Members of traditional pacifist Churches, such as the Quakers, the Mennonites, the Amish etc. were routinely released, while non-religious pacifists found it much more difficult to successfully establish the sincerity of their intentions (Noonan, 1987, p. 255). In Poland, it is illegal to intentionally insult somebody's religious feelings, ${ }^{9}$ while similar regulations do not, needless to say, protect a person's atheist, communist, liberal or other non-religious views and feelings.

${ }^{8}$ This extensive interpretation of religious freedom was reversed by the divided Supreme Court in the 1990s among hot political controversy (Potz, 2008, chap. 2.4, 5.2).

${ }^{9}$ Art. 196 of the Polish penal code. The law is, though, rarely enforced. 
The standard justification of such asymmetry, often invoked, for instance, in communitarian critiques of liberalism, is that religious convictions are not freely chosen in the way philosophical views or political opinions can be, but are instead acquired during socialization, emotionally amplified and felt as moral imperatives. As such, they should be treated in a different way, almost as a given, natural feature of individuals which imposes "objective" restrictions on their behavior and must be taken into account (Sandel, 1993, p. 487). Whatever the merits of this argument, it only confirms that a special status is postulated for religion, which, in turn, translates into the institutional arrangements referred to above.

Together, these phenomena of granting religious statements immunity from scientific scrutiny, recognizing religious persons' claims to rights as unique and the existence of an institutional, including legal, environment altogether beneficial for religious organizations, combine into favorable conditions for religion's political prominence. They do not translate directly or with necessity into political action; nevertheless, the stage has been set.

\section{Political activity}

Notwithstanding these favorable conditions, religion can no longer spur political activity the way it did in pre-modern times or in contemporary non-liberal-democratic political systems. The old-fashioned alliance of the altar with the throne is no longer an option: even if institutionally feasible, it would generate nearly universal social opposition. ${ }^{10}$ Having lost its legitimating power, religion needs to re-legitimate its presence in the democratic public sphere by adopting tactics similar to those of other political actors and deemed acceptable within a given political culture. In addition, religious organizations may complement this mimicry strategy with the use of religion-specific strategies, grounded in their unique capacity of defining their principles and ultimate goals by reference to the sacrum. Let us review this repertoire, using the examples of the Catholic Church in contemporary Poland and the Religious Right movement in the United States.

\section{Mimicry strategies}

Like any other political actor, religious organizations attempt to realize certain goals in the course of their public activity. For the Polish Catholic Church in the post-communist era, these goals included the institutionalization of church-state relations in a way that would not preclude the Church's public presence; retaining its position of moral authority in the society; and securing the material basis of its existence. Some of the methods it used resembled the methods of other democratic actors: it acted as a political principal, as a social movement and as an interest group. ${ }^{11}$

${ }^{10}$ For instance, according to the findings of Wave 6 (2010-2014) of World Values Survey, fewer than $10 \%$, and in most cases only $2-4 \%$ of Europeans think it is essential that religious authorities interpret the laws in democracy (World).

${ }^{11}$ Such a functional way of conceiving of the Church's political behavior seems appropriate, since the Polish Church does not have clearly identifiable structures responsible for particular strategies - it may act 
As a political principal, the Church inspired, since 1989, the creation of Catholic political parties to reflect its position on public issues and thus let it exert an influence on parliamentary politics (Zuba, 2010, pp. 119-120). This approach, however, proved ineffective: Church-sponsored parties did poorly in elections and public opinion was not prepared to accept such direct political influence of the Church. When the failure became clear, the strategy was abandoned by the late 1990s.

As a social movement, the Church displayed significant potential for mass mobilization. This was achieved mainly through Radio Maryja - a Catholic radio station which grew into a community of people sharing a conservative worldview and values (the socalled "Radio Maryja family") and a media concern with its own newspaper, television, mobile network and college, managed by its charismatic founder and leader Fr. Tadeusz Rydzyk. Many mass events organized by Radio Maryja, in the past reportedly gathering up to 500,000 people (Jasna, 2010), are of predominantly religious character (e.g. pilgrimages to the Jasna Góra sanctuary). Others were, however, political demonstrations, letter-writing campaigns and mobilizing support for causes important for both the Church as a whole and Radio Maryja itself. The former included the abortion law and the position on the new constitution and EU accession, and the latter - defending Fr. Rydzyk from prosecution for insulting speech or securing a place on nationwide broadcasting platform for the movement's TV station (Głuchowski, Hołub, 2013, p. 110, $253 \mathrm{ff}$.).

The US Religious Right movement is a significantly different example. Rather than a social movement within a religious group, it is a loose coalition of churches, NGOs, lobbies and other types of political actors, representing various Christian denominations, but united in the goal of stopping what they consider a liberal assault on traditional American values. They stress, among other issues, the public significance of religion, traditional family model, individualism, self-sufficiency and America's special mission. Their political repertoire ranges from direct lobbying of decision-makers, through litigation, to grass-roots lobbying based on mass mobilization of the movement's supporters to take part in demonstrations, vote in state referenda or school board elections, or flood a congressman's office with letters or e-mails. One example of effective political action by a coalition of social actors, including the Mormon Church and some other conservative religious organizations, was the nationwide campaign to block the ratification of the Equal Rights Amendment (Mansbridge, 1986; Potz, 2015).

In their capacity as interest groups, religious organizations influence other political actors, specifically those in positions of authority - organs of government, political parties - to secure their own institutional and material interests. This comes as a natural consequence of their being social entities whose survival as organizations is the prerequisite to the successful fulfillment of their otherworldly mission. In other words, churches lobby the government as interests groups, to be able to execute their God-given mission in their capacity as value-based public actors. In the case of the Polish Catholic Church, the lobbying concerns the model of church-state relations and the financial conditions of the Church's existence. As regards the former, the bishops tried to prevent a doctrine of strict separation to be entered into the new constitution, lobbied for the ratification of the

in all these capacities simultaneously, as the situation dictates. For the American Religious Right, a structural perspective might work better: it could be conceived of as a broad social movement with specialized units - NGOs, lobbies, think-tanks etc. - focused on certain methods of political action. 
concordat with the Vatican and for religious education in public schools. With respect to the latter, the Church was able to secure various forms of financial support from the state (despite the ban on direct funding of religious groups by the government), such as salaries for clerical personnel teaching religion in public schools, funding of Church schools of all levels, including universities, preferential, out-of-court track for the Church's reprivatization claims, various tax exemptions etc. While some of these arrangements are technically available to other religious groups, too (though not necessarily for nonreligious organizations - see: 2 above), the Catholic Church has been by far their biggest beneficiary. The methods of this type of activity range, typically for interest groups, from direct, behind-the-scenes contacts between Church hierarchs and decision-making politicians, letters announcing the position of the episcopate, e.g., critical opinions on drafts of constitution (Sowiński, 2014, p. 666), moral suasion on politicians etc. While not all the postulates of the Church have been realized, the institution has been generally successful in safeguarding its stable legal and material position.

\section{Religion-specific strategies}

While any political actor attempts to impose its interpretation of reality - its truth - on other actors, including the decision-makers, and on public opinion, religious organizations feel specifically authorized to do so. Their values are presented as being of external, supernatural origin, and the positions they take on public issues are firmly grounded in these timeless values, not an effect of political expediency. So, while from the point of view of a political system religious subjects act as creators of public values, they see themselves merely as their transmitters. Religious organizations are thus uniquely value-based political actors. This self-perception generally agrees with public opinion, at least in Poland: while most people reject the Catholic Church's direct intervention in party politics (only 15\% are not offended by priests telling people whom to vote for), $40 \%$ approve of its taking a position on acts of parliament, and more than $60 \%$ feel comfortable with the Church speaking out on moral issues (Grabowska, 2013, p. 2). Thus, it is of paramount importance for the Church, and a precondition of its sustained public influence, to be able to present all the issues it speaks out on, or otherwise deals with in the public sphere as moral issues. This way, a religious organization may both assert its legitimacy as a value-based political actor and, ultimately, attain some of its objectives. Thus, for instance, when taking a position on the legislation regulating in vitro fertilization, the Conference of the Episcopate of Poland stated this distinction unequivocally: "While there can be no compromise on moral issues, in politics compromise is the essence of law-making in a democratic state". The bishops further insisted that this case clearly falls into the moral sphere and therefore the Church is authorized to set "boundaries for the involvement in adopting an immoral law" (Apel, 2015), at least for the Catholic law-makers.

Such an appeal to legislators as Catholics to follow the teachings of the Church shows another weapon that the Church, as opposed to other political actors, may wage in pursuing its goals in the public sphere. In the above mentioned document on the proposed in vitro law, the bishops expressed their concern that members of parliament who 
declare themselves practicing Catholics should "remain in full bond with the community of the Catholic Church and in the disposition to receive Holy Communion." They thus offer guidelines for how these MPs should proceed with the bill, since the support for an "immoral law" may "amount to excluding oneself from the community of the Church" (Apel, 2015). In this way, the Church uses what effectively amounts to the threat of excommunication - withholding of the ultimate rewards which the religious organization administers - to put pressure on decision-makers to make them conform to the Church's agenda.

In the United States, a striking recent example of an attempt to bring a uniquely religious ritual to bear on the political process is the use of imprecatory prayer. Some pastors, including Southern Baptist Wiley Drake of California, one of the first to use the practice, have succeeded in mobilizing thousands of people to curse (usually liberal) politicians with passages from the Old Testament (mainly the Book of Psalms) or selfcomposed prayers. The imprecations are directed against godless laws (e.g., pro-choice legislation or Obamacare) or sinful public officials, with Barack Obama at the top of the list, and the prayers call on God to punish the transgressors, often with severe suffering or death (Pomarański, 2013, pp. 144-147). At times the faithful actually pray for the evil politicians rather than against them - as in the Adopt a Liberal initiative (Adopt) - but the actions are always connected with positions on public issues that the decision-makers in need of prayer took.

A better-known instance of a religious practice turned political weapon is the phenomenon of televangelism. Here, preaching - an essentially religious form of communication, deeply rooted in the Christian and particularly the Protestant tradition - is used to promote religious standpoints on a host of public issues, ranging from sexual ethics to national security and climate change. The specifically political edge of the activity of TV and radio preachers is evident in their targeting particular politicians and addressing specific political decisions, legislative proposals, or legal documents. Not only are these items evaluated from the perspective of a religion-based axiology, but the faithful are prompted to take action on them by expressing discontent and lending electoral, financial or organizational support. The impact of these messages is enhanced by their transmission through media of mass communication (TV and radio broadcast), thus potentially reaching, through cable networks, millions of viewers and listeners. Connected mainly with fundamentalist and evangelical Protestantism, televangelism has been instrumental in the emergence and success of the Religious Right movement (Kintz, Lesage, 1998).

\section{Conclusion: empowerment through religion}

By emulating the behavior of other political actors, religious organizations have been able to situate themselves firmly within the democratic public sphere, successfully countering ideological, normative and institutional developments potentially challenging their position. While these 'mimicry' strategies are easier to justify in the context of democratic politics than the religion-specific strategies, even the latter cannot be rejected offhand by the critics of religion's public role without undermining the entire liberal 
conception of a pluralistic public sphere, where subjects use whatever (legal) means are available to them to further their interests.

In the process, religion serves as a factor of empowerment by generating a significant amount of social/political capital. According to Mark Haugaard,

Social capital refers to the legitimate structuring practices associated with positions of authority that empower a social agent and are recognized as valid either by the rest of society or, in the case of a smaller group, by relevant interacting others. These structuring practices define the levels of empowerment and thus the conditions of possibility of agency associated with the reproduction of any socially constituted position of authority (Haugaard, 2012, p. 81).

These "structuring practices", in the case of religious organizations, consist of political activities geared towards maintaining focal points in the social structure of power, including, among other things, the role of independent authority on a variety of issues broadly defined as "moral"; the capacity to mobilize hundreds of thousands of people to engage politically; and the constant presence in the public education system. Acting from these positions, religious political actors have often been able to impose their cognitive and moral perspectives (interpretations of reality and normative standards) to legitimize their political involvement, and thereby ultimately to empower themselves within a democratic political system.

\section{Bibliography}

Adopt a Liberal. A Liberty Council Prayer-in Action program, https://www.liberty.edu/media/9980/ side/AdoptALiberal.pdf (22.03.2016).

Apel Prezydium Konferencji Episkopatu Polski $w$ zwiqzku z rozpoczęciem prac nad projektem ustawy o medycznym wspomaganiu prokreacji (in vitro) (2015), http://episkopat.pl/ dokumenty/6549.1,Apel_Prezydium_Konferencji_Episkopatu_Polski_w_zwiazku_z_rozpoczeciem_prac_nad_projektem_ustawy_o_medycznym_wspomaganiu_prokreacji_in_vitro. html, 31.03.2015 (24.03.2016).

Atran S. (2002), In Gods We Trust: The Evolutionary Landscape of Religion, Oxford University Press, Oxford.

Carter S. L. (1993), The Culture of Disbelief, BasicBooks, New York.

Casanova J. (2012), Public religions in the modern world, University of Chicago Press, Chicago.

Cohen J. (2007), Deliberative Democracy, in: Deliberation, Participation and Democracy. Can the People Govern?, ed. S. W. Rosenberg, Palgrave Macmillan, New York.

Constitution of Greece, http://www.hri.org/docs/syntagma, 23.03.2016.

Constitution of Ireland, http://www.taoiseach.gov.ie/eng/Historical_Information/The_Constitution/ February_2015_-_Constitution_of_Ireland_.pdf, 21.03.2016.

Constitution of Malta, http://justiceservices.gov.mt/DownloadDocument.aspx?app=lom\&itemid=8566, 23.03.2016.

Constitution of the Kingdom of Norway, http://www.servat.unibe.ch/icl/no00000_.html, 23.03.2016.

Constitution of the Principality of Liechtenstein, http://www1.umn.edu/humanrts/research/liechtenstein-constitution.pdf, 23.03.2016.

Constitution of the Republic of Iceland, http://www.government.is/constitution, 15.03.2016.

Constitution of the Republic of Poland, http://www.sejm.gov.pl/prawo/konst/angielski/kon1.htm, 25.03.2016. 
Constitutional Act of Denmark, http://www.ilo.org/wcmsp5/groups/public/---ed_protect/---protrav/--ilo_aids/documents/legaldocument/wcms_127469.pdf, 22.03.2016.

Dawkins R. (2008), The God Delusion, Mariner Books, Boston-New York.

Delumenau J. (ed.) (1993), Le savant et la foi, Flammarion, Paris.

Furniere A. (2015), Lessons in religion no longer obligatory in Belgium, "FlandersToday", 15.03.2015, http://www.flanderstoday.eu/education/lessons-religion-no-longer-obligatory-belgium, 14.02.2016.

Giuriato L. (2009), Combining Autocracy and Majority Voting: The Canonical Succession Rules of the Latin Church, in: The Political Economy of Theocracy, eds. M. Ferrero, R. Wintrobe, Palgrave Macmillan, New York.

Głuchowski P., Hołub J. (2013), Imperator, Agora, Warszawa.

Grabowska M. (2013), Religia i kościół w przestrzeni publicznej, CBOS, Warszawa, http://www.cbos. pl/SPISKOM.POL/2013/K_170_13.PDF, 25.03.2016.

Haugaard M. (2012), Power and Truth, "European Journal of Social Theory", vol. 15, no. 1.

Jasna Góra: dziś rozpoczyna się Pielgrzymka Rodziny Radia Maryja (2010), http://ekai.pl/diecezje/ x30983/jasna-gora-dzis-rozpoczyna-sie-pielgrzymka-rodziny-radia-maryja, $\quad$ 10.07.2010, 22.03.2016.

Kintz L., Lesage J. (eds.) (1998), Media, Culture, and the Religious Right, University of Minnesota Press, Minneapolis-London.

Kowalczyk K. (2014), Kościót katolicki jako podmiot oddziałujacy na system polityczny, „Wrocławskie Studia Politologiczne", vol. 17.

Llorent-Bedmar V., Cobano-Delgado V. (2014), The Teaching of Religious Education in Public Schools in the Nordic Countries of Europe, "Review of European Studies", vol. 6, no. 4.

Mansbridge J. (1986), Why We Lost the ERA, University of Chicago Press, Chicago-London 1986.

Neuhaus R. J. (1986), The Naked Public Square. Religion and Democracy in America, William B. Eerdmans, Grand Rapids.

Noonan J. T. Jr. (1987), The Believer and the Powers That Are, Macmillan, London-New York.

Poggi G. (2001), Forms of Power, Polity, Cambridge.

Pomarański M. (2013), 'God bless America'. Prayer as a political ritual in the USA, "Annales UMCS. Sectio K - Politologia”, vol. XX, no. 1.

Potz M. (2008), Granice wolności religijnej. Kwestie wolności sumienia i wyznania oraz stosunku państwa do religii w Stanach Zjednoczonych Ameryki, FNP, Wrocław.

Potz M. (2010), The Unfulfilled Promise? Deliberative Democracy vs. Political Participation, "Polish Political Science Yearbook", vol. XXXIX.

Potz M. (2013), Religious doctrine as a factor of stability of political systems. A study of two North American theocracies, "Politics and Religion Journal", vol. 7, no. 2.

Potz M. (2015), A contemporary religious political movement: LDS Church's nation-wide political campaigns, "Annales UMCS. Sectio K; Politologia”, vol. 22, no. 1.

Sandel M. (1993), Freedom of Conscience or Freedom of Choice?, in: Religious Liberty in the Supreme Court. The Cases that Define the Debate over Church and State, ed. T. Eastland, Ethics and Public Policy Center/Eerdmans Publishing, Grand Rapids-Cambridge.

Sherbert v. Verner (1963), 374 U.S. 398 (a decision by the US Supreme Court).

Sowiński S. (2014), Polityka i religia w Polsce po roku 1989, in: Religia i polityka. Zarys problematyki, eds. P. Burgoński, M. Gierycz, Elipsa, Warszawa.

Stewart C. (2015), School system in Italy, http://www.lifeinitaly.com/moving/school-system.asp, 14.02.2016.

Szymanek J. (2011), Konstytucjonalizacja idei państwa wyznaniowego, in: Państwo wyznaniowe. Doktryna, prawo i praktyka, ed. J. Szymanek, Elipsa, Warszawa. 
Wilson D. S., Green W. S. (2007), Evolutionary Religious Studies (ERS): A Beginner's Guide, volution. binghamton.edu/religion/wp-content/uploads/2009/09/BeginnersGuide.pdf, 24.03.2016.

World Values Survey, http://www.worldvaluessurvey.org/WVSOnline.jsp, 21.03.2016.

Zuba K. (2010), The Political Strategies of the Catholic Church in Poland, "Religion, State \& Society", vol. 38 , no. 2 .

\section{Religia jako źródło władzy: strategie przetrwania religii w polityce demokratycznej}

\section{Streszczenie}

Utraciwszy status dominującej formuły legitymizacyjnej w świecie zachodnim, religia została też instytucjonalnie oddzielona od państwa i, w myśl ideologii liberalnej, zepchnięta na margines życia publicznego. Pomimo tych niesprzyjających okoliczności, religia - zarówno jako system idei i norm, jak i w wymiarze instytucjonalnym - zdołała obronić się przed marginalizacją, zapewniając sobie szczególny status wśród innych ideologii. W nauce objawia się to swego rodzaju metodologicznym agnostycyzmem, nakazującym traktować twierdzenia religijne jako niewspółmierne z naukowymi, a zatem niepodlegające krytyce. W polityce, organizacje religijne uzyskały w wielu państwach zachodnich szczególną pozycję, a wolność religijna została ukonstytuowana jako szczególny przypadek swobody wypowiedzi. W swej działalności politycznej organizacje religijne stosują zarówno metody identyczne $\mathrm{z}$ innymi aktorami politycznymi (lobbying, masowa mobilizacja itp.) - co nadaje im legitymację w ramach demokratycznych systemów politycznych - jak i specyficzne strategie religijne. Działania te są w artykule analizowane głównie na przykładach polskich i amerykańskich. Uzbrojone w takie narzędzia, religijne podmioty polityczne mogą wywierać znaczący wpływ na demokratyczne systemy polityczne.

Słowa kluczowe: religia i polityka w Polsce, religia i polityka w USA, politologia religii, ruchy polityczne, religijni aktorzy polityczni w demokracji liberalnej 
